\title{
Enhancing Nutritional Quality of Oil Palm Empty Fruit Bunch for Animal Feed by Using Fiber Cracking'Technology
}

\author{
Anuraga Jayanegara ${ }^{1 *}$, Nabila F. Ardhisty ${ }^{1}$, Sari P. Dewi ${ }^{1}$, Antonius ${ }^{2}$, Roni Ridwan ${ }^{3}$, Erika B. \\ LACONI $^{1}$, Nahrowi ${ }^{1}$, MUhammad Ridla ${ }^{1}$
}

${ }^{1}$ Department of Nutrition and Feed Technology, Faculty of Animal Science, Bogor Agricultural University, Bogor 16680; ' Goat Research Station, Indonesian Agency for Agricultural Research and Development, PO BOX 1, Galang, Sei Putih 20585; ${ }^{3}$ Biotechnology Research Center, Indonesian Academy of Sciences, Jl. Raya Bogor Km 46, Cibinong, Bogor 16911, Indonesia.

\begin{abstract}
This experiment aimed to enhance nutritional quality of oil palm empty fruit bunch (OPEFB) by combining urea treatment and high temperature and pressure $\left(135^{\circ} \mathrm{C}, 2.3 \mathrm{~atm}\right)$ using fiber cracking technology $(\mathrm{FCT})$. The OPEFB was subjected to the following treatments: T1 (untreated OPEFB), T2 (OPEFB + FCT), T3 (OPEFB + 1\% urea + FCT), T4 (OPEFB + 2\% urea + FCT), T5 (OPEFB + 3\% urea + FCT), T6 (OPEFB + 4\% urea + FCT) and T7 $(\mathrm{OPEFB}+5 \%$ urea $+\mathrm{FCT})$, each in four replicates. Samples were determined for neutral detergent fiber (NDF), acid detergent fiber $(\mathrm{ADF})$ and lignin contents, and were incubated in vitro with rumen fluid and buffer mixture. Results showed that treatment using FCT (T2) decreased NDF, ADF, cellulose and lignin contents of OPEFB. Combination between FCT and 1-5\% urea (T3-T7) further decreased the fiber fractions, and addition 5\% urea + FCT (T7) resulted in the lowest NDF, ADF, cellulose and lignin contents of OPEFB. Such fiber decrease of OPEFB due to FCT and urea was accompanied with significant increase of in vitro total gas production, gas production rate, total volatile fatty acid, ammonia, in vitro dry matter digestibility and in vitro organic matter digestibility as compared to control $(\mathrm{P}<0.05)$. However, methane emission was unaltered by FCT and/or urea treatments.
\end{abstract}

Keywords | Fiber cracking, Urea treatment, Oil palm, By-product, In vitro rumen.

Editor | Kuldeep Dhama, Indian Veterinary Research Institute, Uttar Pradesh, India.

Received | October 06, 2018; Accepted | November 20, 2018; Published | December 29, 2018

*Correspondence | Anuraga Jayanegara, Department of Nutrition and Feed Technology, Faculty of Animal Science, Bogor Agricultural University, Bogor 16680, Indonesia; Email: anuraga.jayanegara@gmail.com

Citation | Jayanegara A, Ardhisty NF, Dewi SP, Antonius, Ridwan R, Laconi EB, Nahrowi, Ridla M (2019). Enhancing nutritional qualityof oil palm empty fruit bunch for animal feed by using fiber cracking technology. Adv. Anim. Vet. Sci. 7(3): 157-163.

DOI | http://dx.doi.org/10.17582/journal.aavs/2019/7.3.157.163

ISSN (Online) | 2307-8316; ISSN (Print) | 2309-3331

Copyright (C) 2019 Jayanegara et al. This is an open access article distributed under the Creative Commons Attribution License, which permits unrestricted use, distribution, and reproduction in any medium, provided the original work is properly cited.

\section{INTRODUCTION}

$\mathrm{I}$ ndonesia is currently the world largest producer of oil palm products especially in the form of crude palm oil. This is possible since total oil palm plantation area in Indonesia is the largest among other countries, i.e. 8,150,000 ha, followed by Malaysia (4,620,000 ha), Thailand (720,000 ha), Nigeria (440,000 ha), Colombia (354,000 ha) and others (Garcia-Nunez et al., 2016). Oil palm plantation, apart from its main products, also produces significant amount of residual biomass such as oil palm trunk, oil palm frond, oil palm empty fruit bunch (OPEFB), kernel shell, mesocarp fiber and palm oil mill effluent (POME).
Production of palm oil is approximately $10 \%$ from total biomass and the remaining is regarded as residual biomass (Ooi et al., 2017). Further, considering conversion factors from Stichnothe and Schuchardt (2010), processing of 100 $\mathrm{kg}$ of fresh fruit bunch (FFB) would result $20 \mathrm{~kg}$ of crude palm oil and $23 \mathrm{~kg}$ of OPEFB. On dry matter basis, two thirds of oil palm residue is originated from oil palm trunk and oil palm frond whereas one third is derived from FFB processing residues (Sulaiman et al., 2010). Such huge amounts of oil palm residues indicate their potency to be used as animal feeds particularly for ruminants since these residues (except POME) generally contain high proportion of fiber (cellulose, hemicellulose and lignin) but low 
proportion of protein (Ooi et al., 2017).

With regard to OPEFB, the biomass was reported to contain $15 \pm 8.9 \%$ lignin, $43 \pm 15.1 \%$ cellulose and $21 \pm 6.3 \%$ hemicellulose, and $0.6 \pm 0.4 \%$ nitrogen (or equal to $3.75 \pm 2.5 \%$ crude protein) (Garcia-Nunez et al., 2016). Such nutrient profile is of lower quality in comparison to common agricultural residues fed to ruminant livestock like rice straw (Muhammad et al., 2014; McCan et al., 2017) or oil palm frond (Imsya et al., 2013; Ebrahimi et al., 2015). A feeding experiment on sheep demonstrated that replacement of field grass by fermented OPEFB decreased dry matter intake, average daily gain and nitrogen retention of the animals by $16.4,70.0$ and $42.5 \%$, respectively (Akbar, 2007). It is therefore apparent that OPEBF should be treated through delignification process by means of biological, physical and/or chemical treatment prior to further use (Tsabitah et al., 2014). Urea treatment is able to concomitantly break down lignocellulose component (Van Soest, 2006; Laconi and Jayanegara, 2015) and add certain amount of nitrogen for microbial protein synthesis in the rumen (Gunun et al., 2016). However, conventional urea treatment is relatively time consuming and requires about 3-7 weeks before the feeds can be consumed by the animals (Jayanegara et al., 2017). In our previous study, combination between urea treatment at $1 \%$ addition level and elevated temperature and pressure $\left(121^{\circ} \mathrm{C}, 1.4 \mathrm{~atm}\right)$ for 30 min using an autoclave increased dry matter- and organic matter digestibility of rice straw by 23.3 and $25.6 \%$, respectively (Jayanegara et al., 2017). Such treatment was better in comparison to conventional urea treatment in which the rice straw was incubated for four weeks.

Such treatment combination may also be applied to OPEFB biomass in order to enhance its nutritional quality. However, it has to be noted from that experiment that the treatment did not decrease the contents of neutral detergent fiber (NDF) and acid detergent fiber (ADF) in rice straw (Jayanegara et al., 2017). With the even lower nutritional quality of OPEFB than that of rice straw, it seems that level of urea added, temperature and pressure applied, and incubation period need to be elevated in order to effectively increase OPEFB quality. This experiment therefore aimed to enhance nutritional quality of OPEFB by combining urea treatment and high temperature and pressure $\left(135^{\circ} \mathrm{C}, 2.3 \mathrm{~atm}\right)$, and incubated for $2.5 \mathrm{~h}$. Since such levels of temperature and pressure could not be achieved by a normal autoclave, treatment was performed in a special incubator called Fiber Cracking Technology (FCT).

\section{MATERIALS AND METHODS}

\section{Sample Preparation and Treatment}

The OPEFB sample was collected from PT Perkebunan
Nusantara VIII, Cikasungka, Bogor. Sample was chopped, oven-dried at $60^{\circ} \mathrm{C}$ for $48 \mathrm{~h}$ and ground by a hammer mill to pass a $1 \mathrm{~mm}$ screen. Ground OPEFB sample was subjected to the following experimental treatments:
T1 : Untreated OPEFB (control)
T2 : OPEFB + FCT
T3 : OPEFB + 1\% urea + FCT
T4 : OPEFB + $2 \%$ urea + FCT
T5 : OPEFB + $3 \%$ urea + FCT
T6 : OPEFB $+4 \%$ urea + FCT
T7 : OPEFB + 5\% urea + FCT

The FCT was an incubator with a capacity of 501 and able to generate high temperature and pressure up to $200^{\circ} \mathrm{C}$ and $5 \mathrm{~atm}$, respectively. In the present experiment, FCT was set at $135^{\circ} \mathrm{C}$ and $2.3 \mathrm{~atm}$ for $2.5 \mathrm{~h}$. Urea $\left(\mathrm{CO}\left(\mathrm{NH}_{2}\right)_{2}\right)$ was solubilized in water at $1: 25 \mathrm{~kg} / \mathrm{l}$ before being added to OPEFB, and the solution was sprayed to the sample, mixed thoroughly and then put into the FCT. All treatments were performed in four replicates.

\section{Chemical Composition Analysis}

Untreated and treated OPEFB samples were determined for neutral detergent fiber (NDF), acid detergent fiber (ADF) and lignin contents according to Van Soest et al. (1991). To determine NDF, $1 \mathrm{~g}$ sample was boiled in $100 \mathrm{ml}$ neutral detergent solution for $1 \mathrm{~h}$ and the residue was regarded as NDF. Determination of ADF was similar to that of NDF but the solution used was acid detergent solution. Cellulose content was estimated by difference between NDF and ADF. Lignin was determined by adding $72 \%$ sulfuric acid to ADF residue and kept for $3 \mathrm{~h}$, and rinsed with hot water and aceton afterwards. The residue was subsequently oven-dried at $105^{\circ} \mathrm{C}$ for $4 \mathrm{~h}$ and burned at $600^{\circ} \mathrm{C}$ in a furnace. Chemical composition determination was conducted in duplicate.

\section{IN Vitro Incubation Procedure}

Samples of OPEFB were incubated in vitro with rumen fluid and McDougall buffer mixture according to Theodorou et al. (1994). Rumen inoculum (from fluid and solid particle) was obtained from two fistulated Ongole crossbred cattle. Approximately $750 \mathrm{mg}$ sample was inserted into a $125 \mathrm{ml}$ serum bottle and added with rumen fluid and buffer mixture, each of 15 and $60 \mathrm{ml}$, respectively. Allocation of treatments into serum bottles was according to a randomized complete block design. Incubation was carried out in four replicates (four bottles per replicate,two bottles were incubated for $2 \times 24 \mathrm{~h}$ and incubation period of the other two bottles was extended to $72 \mathrm{~h}$ for measurement of gas production kinetics). Serum bottles werethen immediately sealed with butyl rubber stoppers and aluminum crimp seals. Incubation was conducted at a constant temperature of $39^{\circ} \mathrm{C}$. Total gas production together with 
methane was recorded during the incubation period. After $24 \mathrm{~h}$, supernatant was collected for determinations of total volatile fatty acid (VFA) and ammonia concentrations (Jayanegara et al., 2016). Residue was further incubated with $75 \mathrm{ml}$ pepsin- $\mathrm{HCl} 0.2 \mathrm{~N}$ solution for another $24 \mathrm{~h}$ to measure in vitro dry matter digestibility (IVDMD) and in vitro organic matter digestibility (IVOMD), and corrected for blanks (Tilley and Terry, 1963).

\section{Data Analysis}

Data on gas production kinetics during $72 \mathrm{~h}$ incubation were fitted with the following (non-linear) exponential and Gompertz models:

Exponential model

Gompertz model

$$
\begin{aligned}
& : \mathrm{V}_{(\mathrm{t})}=\mathrm{V}_{\mathrm{f}}\left(1-\mathrm{e}^{-\mathrm{kt}}\right) \\
& : \mathrm{V}_{(\mathrm{t})}=\mathrm{V}_{\mathrm{f}} \mathrm{e}^{-\mathrm{L} \mathrm{e}^{-\mathrm{kt}}}
\end{aligned}
$$

where $V_{(t)}$ is volume of gas production (ml) at time $t$, $t$ is incubation period $(\mathrm{h}), \mathrm{V}_{\mathrm{f}}$ is asymptotic gas production $(\mathrm{ml})$, e is Euler's number, $\mathrm{L}$ is lag time (h), and $\mathrm{k}$ is gas production rate constant $(1 / \mathrm{h})$. Goodness of fit of the models was evaluated through coefficient of determination $\left(\mathrm{R}^{2}\right)$ and mean square error (MSE). Further, analysis of variance (ANOVA) was applied to all data and continued with Duncan's multiple range test when there was a significant difference among treatments at $\mathrm{P}<0.05$.

\section{RESULTS AND DISCUSSION}

\section{Chemical Composition}

Treatment using FCT (T2) decreased NDF, ADF, cellulose and lignin contents of OPEFB (Table 1). It is apparent that high temperature and pressure generated by FCT degrade certain fiber component present in OPEFB. Van Soest (2006) described that fiber decrease by high temperature and pressure may occurrsince such condition promotes release of acetyl groups from fiber structure, increases substrate acidity and then finally induces solubilization of fiber component. Combination between FCT and 1-5\% urea (T3-T7) further decreased the fiber fractions. Addition 5\% urea + FCT (T7) resulted in the lowest NDF, $\mathrm{ADF}$, cellulose and lignin contents of OPEFB among all treatments. In comparison to untreated OPEFB, T7 decreased NDF, ADF, cellulose and lignin by 17.3, 22.9, 25.2 and $15.6 \%$, respectively. During urea treatment, the compound is converted to ammonia and absorbed to OPEFB cell wall to cause severance between lignin and cellulose or hemicellulose complexes (Sarnklong et al., 2010). High temperature and pressure from FCT apparently induced faster reaction for ammonia to degrade lignocellulose complex present in OPEFB. In agreement with our study, pretreatment of OPEFB by using ammonia fiber expansion or AFEX system (1:1 ammonia to biomass loading, $135^{\circ} \mathrm{C}$, pressure 35-50 bar, $45 \mathrm{~min}$ ) decreased its lignin content from 23.38 to $16.84 \%$ DM (Abdul et al., 2016). It was further demonstrated that, by using Fourier transform infrared spectroscopy, there were disappearance of peaks at $1738 \mathrm{~cm}^{-1}$ and $1241 \mathrm{~cm}^{-1}$ in the AFEX pretreated OPEFB. These peaks are regarded as carboxylic and carbonyl bonds, respectively, that part of intermolecular ester bonds between carbohydrates and lignin complex. Therefore such disappearance indicated the disruption of lignocellulose complex in OPEFB by AFEX pretreatment (Abdul et al., 2016).

Table 1: Neutral detergent fiber (NDF), acid detergent fiber (ADF), cellulose and lignin contents (\% dry matter) of oil palm empty fruit bunch (OPEFB) treated with Fiber Cracking Technology (FCT).

\begin{tabular}{|lllll|}
\hline Treatment & NDF & ADF & Cellulose & Lignin \\
\hline T1 & 80.5 & 63.0 & 47.6 & 15.4 \\
\hline T2 & 79.7 & 58.2 & 43.1 & 15.1 \\
\hline T3 & 78.4 & 56.7 & 42.3 & 14.4 \\
T4 & 78.2 & 55.2 & 40.9 & 14.3 \\
T5 & 74.2 & 54.2 & 40.1 & 14.1 \\
T6 & 69.8 & 52.7 & 39.2 & 13.5 \\
\hline T7 & 66.6 & 48.6 & 35.6 & 13.0 \\
\hline
\end{tabular}

T1, untreated OPEFB (control); T2, OPEFB + FCT; T3, OPEFB + $1 \%$ urea + FCT; T4, OPEFB + $2 \%$ urea + FCT; T5, OPEFB + 3\% urea + FCT; T6, OPEFB + 4\% urea + FCT; T7, OPEFB + $5 \%$ urea + FCT.

\section{In Vitro Gas Production Kinetics}

A significant increase of in vitro gas production was observed in the incubation of OPEFB treated with FCT than that of control at various incubation periods $(\mathrm{P}<0.05$; Table 2). Addition of urea at different concentrations combined with FCT further significantly increased gas production $(\mathrm{P}<0.05)$ and followed a linear pattern with increasing level of urea. Parameter of in vitro gas production rate showed similar pattern with total gas production parameter (Table 3). Gas production rate of all treatments decreased with increasing length of incubation period. With regard to kinetic parameters of in vitro gas production, higher level of urea addition + FCT led to a higher asymptotic gas production $\left(V_{f}\right)$; this was true when fitted with both exponential and Gompertz models (Table 4). Gas production rate constant $(\mathrm{k})$ was higher with increasing concentration of urea addition when fitted with Gompertz equation, but it was insignificant among treatments in the exponential model. Lag time (L) of gas production was also not significant among treatments. Gompertz model showed better goodness of fit than exponential model as shown by the higher $\mathrm{R}^{2}$ and lower MSE values.

Higher gas production of OPEFB treated with FCT or FCT + urea was apparently related to lignocellulose degra- 
Table 2: In vitro gas production (ml) of oil palm empty fruit bunch (OPEFB) treated with Fiber Cracking Technology (FCT) at various incubation period.

\begin{tabular}{lllllllllll} 
Treatment & \multicolumn{9}{l}{ Incubation period (h) } \\
T1 & $\mathbf{2}$ & $\mathbf{4}$ & $\mathbf{6}$ & $\mathbf{8}$ & $\mathbf{1 0}$ & $\mathbf{1 2}$ & $\mathbf{2 4}$ & $\mathbf{3 6}$ & $\mathbf{4 8}$ & $\mathbf{7 2}$ \\
T2 & $11^{\mathrm{a}}$ & $19^{\mathrm{a}}$ & $21^{\mathrm{a}}$ & $22^{\mathrm{a}}$ & $23^{\mathrm{a}}$ & $25^{\mathrm{a}}$ & $29^{\mathrm{a}}$ & $33^{\mathrm{a}}$ & $37^{\mathrm{a}}$ & $43^{\mathrm{a}}$ \\
T3 & $14^{\mathrm{b}}$ & $22^{\mathrm{b}}$ & $25^{\mathrm{b}}$ & $27^{\mathrm{b}}$ & $28^{\mathrm{b}}$ & $31^{\mathrm{b}}$ & $37^{\mathrm{b}}$ & $41^{\mathrm{b}}$ & $46^{\mathrm{b}}$ & $52^{\mathrm{b}}$ \\
T4 & $16^{\mathrm{c}}$ & $25^{\mathrm{c}}$ & $27^{\mathrm{c}}$ & $30^{\mathrm{c}}$ & $32^{\mathrm{c}}$ & $34^{\mathrm{c}}$ & $41^{\mathrm{c}}$ & $45^{\mathrm{c}}$ & $50^{\mathrm{c}}$ & $56^{\mathrm{c}}$ \\
T5 & $18^{\mathrm{d}}$ & $27^{\mathrm{d}}$ & $31^{\mathrm{d}}$ & $34^{\mathrm{d}}$ & $36^{\mathrm{d}}$ & $39^{\mathrm{d}}$ & $45^{\mathrm{d}}$ & $51^{\mathrm{d}}$ & $56^{\mathrm{d}}$ & $62^{\mathrm{d}}$ \\
T6 & $19^{\mathrm{d}}$ & $29^{\mathrm{d}}$ & $33^{\mathrm{e}}$ & $35^{\mathrm{d}}$ & $37^{\mathrm{d}}$ & $41^{\mathrm{d}}$ & $47^{\mathrm{e}}$ & $54^{\mathrm{e}}$ & $60^{\mathrm{e}}$ & $65^{\mathrm{e}}$ \\
T7 & $21^{\mathrm{e}}$ & $33^{\mathrm{e}}$ & $37^{\mathrm{f}}$ & $40^{\mathrm{e}}$ & $44^{\mathrm{e}}$ & $47^{\mathrm{e}}$ & $53^{\mathrm{f}}$ & $59^{\mathrm{f}}$ & $64^{\mathrm{f}}$ & $70^{\mathrm{f}}$ \\
SEM & $22^{\mathrm{f}}$ & $34^{\mathrm{e}}$ & $37^{\mathrm{f}}$ & $42^{\mathrm{f}}$ & $45^{\mathrm{e}}$ & $48^{\mathrm{e}}$ & $55^{\mathrm{f}}$ & $63^{\mathrm{g}}$ & $68^{\mathrm{g}}$ & $74^{\mathrm{g}}$ \\
P-value & 0.52 & 0.72 & 0.84 & 0.94 & 1.04 & 1.12 & 1.19 & 1.38 & 1.42 & 1.43 \\
\hline De & $<0.001$ & $<0.001$ & $<0.001$ & $<0.001$ & $<0.001$ & $<0.001$ & $<0.001$ & $<0.001$ & $<0.001$ & $<0.001$
\end{tabular}

Different superscripts in the same solumn are significantly different at $\mathrm{P}<0.05$.

T1, untreated OPEFB (control); T2, OPEFB + FCT; T3, OPEFB + 1\% urea + FCT; T4, OPEFB + $2 \%$ urea + FCT; T5, OPEFB + $3 \%$ urea + FCT; T6, OPEFB + 4\% urea + FCT; T7, OPEFB + 5\% urea + FCT; SEM, standard error of mean.

Table 3: In vitro gas production rate $(\mathrm{ml} / \mathrm{h})$ of oil palm empty fruit bunch (OPEFB) treated with Fiber Cracking Technology (FCT) at various incubation period.

\begin{tabular}{|c|c|c|c|c|c|c|c|c|c|c|}
\hline \multirow[t]{2}{*}{ Treatment } & \multicolumn{10}{|c|}{ Incubation period (h) } \\
\hline & 2 & 4 & 6 & 8 & 10 & 12 & 24 & 36 & 48 & 72 \\
\hline $\mathrm{T} 1$ & $5.6^{\mathrm{a}}$ & $4.7^{\mathrm{a}}$ & $3.5^{\mathrm{a}}$ & $2.7^{\mathrm{a}}$ & $2.3^{\mathrm{a}}$ & $2.1^{\mathrm{a}}$ & $1.2^{\mathrm{a}}$ & $0.91^{\mathrm{a}}$ & $0.78^{\mathrm{a}}$ & $0.60^{\mathrm{a}}$ \\
\hline $\mathrm{T} 2$ & $7.1^{\mathrm{b}}$ & $5.6^{\mathrm{b}}$ & $4.1^{\mathrm{b}}$ & $3.4^{\mathrm{b}}$ & $2.8^{\mathrm{b}}$ & $2.6^{\mathrm{b}}$ & $1.5^{\mathrm{b}}$ & $1.15^{\mathrm{b}}$ & $0.95^{\mathrm{b}}$ & $0.72^{\mathrm{b}}$ \\
\hline T3 & $7.8^{c}$ & $6.1^{\mathrm{c}}$ & $4.5^{c}$ & $3.7^{\mathrm{c}}$ & $3.2^{c}$ & $2.9^{c}$ & $1.7^{\mathrm{c}}$ & $1.26^{c}$ & $1.04^{c}$ & $0.77^{c}$ \\
\hline $\mathrm{T} 4$ & $8.8^{\mathrm{d}}$ & $6.8^{\mathrm{d}}$ & $5.1^{\mathrm{d}}$ & $4.2^{\mathrm{d}}$ & $3.6^{\mathrm{d}}$ & $3.2^{\mathrm{d}}$ & $1.9^{\mathrm{d}}$ & $1.42^{\mathrm{d}}$ & $1.18^{\mathrm{d}}$ & $0.86^{\mathrm{d}}$ \\
\hline T5 & $9.3^{\mathrm{d}}$ & $7.2^{\mathrm{d}}$ & $5.5^{\mathrm{e}}$ & $4.4^{\mathrm{d}}$ & $3.7^{\mathrm{d}}$ & $3.4^{\mathrm{d}}$ & $2.0^{\mathrm{e}}$ & $1.50^{\mathrm{e}}$ & $1.24^{\mathrm{e}}$ & $0.91^{\mathrm{e}}$ \\
\hline T6 & $10.3^{e}$ & $8.3^{\mathrm{e}}$ & $6.2^{\mathrm{f}}$ & $5.0^{\mathrm{e}}$ & $4.4^{\mathrm{e}}$ & $3.9^{\mathrm{e}}$ & $2.2^{\mathrm{f}}$ & $1.64^{\mathrm{f}}$ & $1.33^{\mathrm{f}}$ & $0.97^{\mathrm{f}}$ \\
\hline $\mathrm{T} 7$ & $11.2^{\mathrm{f}}$ & $8.4^{\mathrm{e}}$ & $6.2^{\mathrm{f}}$ & $5.3^{f}$ & $4.5^{\mathrm{e}}$ & $4.0^{e}$ & $2.3^{f}$ & $1.76^{\mathrm{g}}$ & $1.42^{\mathrm{g}}$ & $1.03^{g}$ \\
\hline SEM & 0.26 & 0.18 & 0.14 & 0.12 & 0.10 & 0.09 & 0.05 & 0.04 & 0.03 & 0.02 \\
\hline $\mathrm{P}$-value & $<0.001$ & $<0.001$ & $<0.001$ & $<0.001$ & $<0.001$ & $<0.001$ & $<0.001$ & $<0.001$ & $<0.001$ & $<0.001$ \\
\hline
\end{tabular}

Different superscripts in the same solumn are significantly different at $\mathrm{P}<0.05$.

T1, untreated OPEFB (control); T2, OPEFB + FCT; T3, OPEFB + 1\% urea + FCT; T4, OPEFB + 2\% urea + FCT; T5, OPEFB + $3 \%$ urea + FCT; T6, OPEFB + 4\% urea + FCT; T7, OPEFB + 5\% urea + FCT; SEM, standard error of mean.

Table 4: In vitro gas production kinetic parameters of oil palm empty fruit bunch (OPEFB) treated with Fiber Cracking Technology (FCT).

\begin{tabular}{llllllllll} 
Treatment & \multicolumn{9}{l}{ Exponential } \\
& $\mathbf{V}_{\mathbf{f}}$ & $\mathbf{k}$ & $\mathbf{R}^{2}$ & $\mathbf{M S E}$ & $\mathbf{V}_{\mathbf{f}}$ & $\mathbf{L}$ & $\mathbf{k}$ & $\mathbf{R}^{2}$ & \multicolumn{1}{c}{ MSE } \\
T1 & $36^{\mathrm{a}}$ & 0.125 & 0.800 & 20.6 & $46^{\mathrm{a}}$ & 1.14 & $0.044^{\mathrm{a}}$ & 0.943 & 6.7 \\
T2 & $45^{\mathrm{b}}$ & 0.120 & 0.851 & 23.8 & $51^{\mathrm{b}}$ & 1.10 & $0.055^{\mathrm{ab}}$ & 0.958 & 7.7 \\
T3 & $49^{\mathrm{c}}$ & 0.123 & 0.873 & 24.3 & $54^{\mathrm{b}}$ & 1.09 & $0.063^{\mathrm{bc}}$ & 0.957 & 8.5 \\
T4 & $54^{\mathrm{d}}$ & 0.128 & 0.877 & 28.9 & $60^{\mathrm{c}}$ & 1.07 & $0.065^{\mathrm{bc}}$ & 0.953 & 11.0 \\
T5 & $57^{\mathrm{e}}$ & 0.124 & 0.864 & 35.6 & $64^{\mathrm{d}}$ & 1.08 & $0.062^{\mathrm{bc}}$ & 0.958 & 11.4 \\
T6 & $62^{\mathrm{f}}$ & 0.145 & 0.890 & 31.6 & $66^{\mathrm{d}}$ & 1.08 & $0.092^{\mathrm{d}}$ & 0.944 & 16.0 \\
T7 & $66^{\mathrm{g}}$ & 0.133 & 0.884 & 39.2 & $71^{\mathrm{e}}$ & 1.06 & $0.073^{\mathrm{c}}$ & 0.958 & 14.5 \\
SEM & 1.36 & 0.003 & & & 1.20 & 0.016 & 0.003 & & \\
P-value & $<0.001$ & 0.128 & & & $<0.001$ & 0.852 & $<0.001$ & &
\end{tabular}

Different superscripts in the same solumn are significantly different at $\mathrm{P}<0.05$. T1, untreated OPEFB (control); T2, OPEFB + FCT; T3, OPEFB + 1\% urea + FCT; T4, OPEFB + 2\% urea + FCT; T5, OPEFB + 3\% urea + FCT; T6, OPEFB + 4\% urea + FCT; T7, OPEFB + 5\% urea + FCT. $V_{\text {f }}$ asymptotic gas production $(\mathrm{ml})$; L, lag time $(\mathrm{h})$; $\mathrm{k}$, gas production rate constant $(1 / \mathrm{h})$; $\mathrm{R}^{2}$, coefficient of determination; MSE, mean square error; SEM, standard error of mean. 
Table 5: In vitro ruminal fermentation parameters of oil palm empty fruit bunch (OPEFB) treated with Fiber Cracking Technology (FCT) at $24 \mathrm{~h}$ incubation period.

\begin{tabular}{|c|c|c|c|c|c|c|}
\hline Treatment & $\begin{array}{l}\text { VFA } \\
(\mathrm{mmol} / \mathrm{l})\end{array}$ & $\begin{array}{l}\mathrm{NH}_{3} \\
(\mathrm{mmol} / \mathrm{l})\end{array}$ & $\begin{array}{l}\text { IVDMD } \\
\text { (\%) }\end{array}$ & $\begin{array}{l}\text { IVOMD } \\
\text { (\%) }\end{array}$ & $\begin{array}{l}\mathrm{CH}_{4} / \mathrm{DDM} \\
(\mathrm{ml} / \mathrm{g})\end{array}$ & $\begin{array}{l}\mathrm{CH}_{4} / \mathrm{DOM} \\
(\mathrm{ml} / \mathrm{g})\end{array}$ \\
\hline $\mathrm{T} 1$ & $72^{\mathrm{a}}$ & $7.6^{\mathrm{a}}$ & $34.0^{\mathrm{a}}$ & $30.9^{a}$ & 40.1 & 49.9 \\
\hline $\mathrm{T} 2$ & $77^{\mathrm{b}}$ & $8.0^{\mathrm{ab}}$ & $39.0^{\mathrm{b}}$ & $35.9^{\mathrm{b}}$ & 39.1 & 48.0 \\
\hline T3 & $85^{c}$ & $8.3^{\mathrm{bc}}$ & $42.8^{c}$ & $39.6^{c}$ & 38.9 & 47.6 \\
\hline $\mathrm{T} 4$ & $93^{d}$ & $8.5^{c}$ & $45.4^{\mathrm{d}}$ & $42.3^{\mathrm{d}}$ & 38.7 & 46.9 \\
\hline T5 & $102^{e}$ & $9.2^{\mathrm{d}}$ & $47.3^{\mathrm{e}}$ & $44.0^{\mathrm{e}}$ & 38.6 & 46.9 \\
\hline T6 & $112^{\mathrm{f}}$ & $9.2^{\mathrm{d}}$ & $49.8^{f}$ & $46.6^{f}$ & 38.8 & 46.9 \\
\hline $\mathrm{T} 7$ & $120^{g}$ & $9.5^{\mathrm{d}}$ & $51.9^{g}$ & $48.8^{g}$ & 37.6 & 45.2 \\
\hline SEM & 2.33 & 0.10 & 0.79 & 0.78 & 0.50 & 0.62 \\
\hline $\mathrm{P}$-value & $<0.001$ & $<0.001$ & $<0.001$ & $<0.001$ & 0.935 & 0.638 \\
\hline
\end{tabular}

Different superscripts in the same solumn are significantly different at $\mathrm{P}<0.05$.

T1, untreated OPEFB (control); T2, OPEFB + FCT; T3, OPEFB + 1\% urea + FCT; T4, OPEFB + $2 \%$ urea + FCT; T5, OPEFB + $3 \%$ urea + FCT; T6, OPEFB + 4\% urea + FCT; T7, OPEFB + 5\% urea + FCT.

VFA, volatile fatty acid; $\mathrm{NH}_{3}$, ammonia; IVDMD, in vitro dry matter digestibility; IVOMD, in vitro organic matter digestibility; $\mathrm{CH}_{4} / \mathrm{DDM}$, methane per digestible dry matter; $\mathrm{CH}_{4} / \mathrm{DOM}$, methane per digestible organic matter; SEM, standard error of mean.

radation to result simpler and more fermentable carbohydrate forms. Further, FCT causes expansion of OPEFB cell wall, making easier for rumen microbes to colonize and degrade fiber component. Gas production in an in vitro rumen fermentation system is resulted from microbial degradation on feed components particularly carbohydrate. Different tipe of carbohydrate such as fiber, starch, oligosaccharide and simple sugar (monosaccharide) reveals different rate of gas production. Since starch degradation in the rumen is faster than fiber degradation, its gas production rate is faster as well. Similarly, fermentation of simple sugar is faster in comparison to starch. Fermentation of protein also produces gas but its amount is smaller than that of carbohydrate (Getachew et al., 1998). Lipid contributes to negligible gas production since fatty acids, the main components of lipid, are not degraded and $\beta$-oxidized by rumen microbes; they are hydrogenated (in case of unsaturated fatty acids) by certain microbial species to result various fatty acid isomers with lower degree of desaturation (Jayanegara et al., 2012). In addition, gas is also resulted from buffering process of bicarbonate buffer on VFA production during fermentation period (Jayanegara et al., 2017). Decrease of gas production rate with increasing length of incubation period reflects less substrate available for microbial degradation and fermentation.

Comparing between exponential and Gompertz in vitro gas production kinetic models, higher goodness of fit of Gompertz model in comparison to exponential model was also observed by Peripolli et al. (2014). The authors compared different gas production models for ruminant diets containing crude glycerol and found that Gompertz model had lower MSE (6.33 vs 24.5) and higher $\mathrm{R}^{2}$ (0.99 vs 0.97 ) than that of exponential model. Exponential model assumes that gas production rate depends only on available substrate after lag time is accomplished, whereas Gompertz model assumes that specific gas production rate is proportional to microbial biomass (Peripolli et al., 2014). Despite such higher accuracy of Gompertz model, another model namely dual-pool logistic model offers even higher goodness of fit and nutritionally is more relevant for describing profile of in vitro gas production kinetics. In the dual-pool model, gas production is divided into two pools or fractions that represent fast and slow digestion rates and generally the model shows higher accuracy in comparison to first order kinetic functions like exponential and Gompertz model (Groot et al., 1996).

\section{IN Vitro Rumen Fermentation, Digestibility And Methane Emission}

The FCT treatment (T2) significantly increased total VFA concentration, IVDMD and IVOMD of OPEFB in comparison to that of control $(\mathrm{P}<0.05 ;$ Table 5$)$. Increasing level of urea addition led to higher values of VFA, IVDMD and IVOMD. Highest level of urea addition (5\%) + FCT(T7) increased VFA, IVDMD and IVOMD of OPEFB by 66.7, 52.6 and 57.9\%. The VFA and IVOMD parameters were highly correlated $(\mathrm{P}<0.001)$ with total gas production (Figure 1). Ruminal ammonia concentration modestly increased with higher level of urea addition by following a quadratic pattern. Methane emission of OPEFB per unit of digestible $\mathrm{DM}$ or OM was unaltered by FCT or urea + FCT treatments.

An increase of IVDMD and IVOMD of OPEFB treated with FCT and/or urea is apparently related to lignocellulose degradation and expansion of cell wall as previously explained. Cell wall expansion due to ammonia or urea treatment was also reported by Mahmud-Ali and Bechtold (2015). Therefore there are interconnections (positive 
relationships) among digestibility, gas production and total VFA concentration. Positive correlation between feed digestibility and in vitro gas production was observed by other authors (Plaizier and Li, 2013). Concomitant increase of total VFA concentration and gas production is expected since both parameters are end products of microbial metabolism in the rumen during nutrient degradation and fermentation (Morvay et al., 2011). Ammonia concentration increase in the incubation of OPEFB treated with urea + FCT may indicate conversion of urea to ammonia under rumen environment. Urea, after being converted to ammonia in the rumen, provides additional advantage by acting as a precursor for microbial protein synthesis and thereafter for supporting protein demand of ruminant livestock (Gunun et al., 2016). Ammonia is an intermediate product of protein metabolism in the rumen; its concentration depends on protein degradation rate, microbial protein synthesis and absorption through rumen villi (Sinclair et al., 2014).

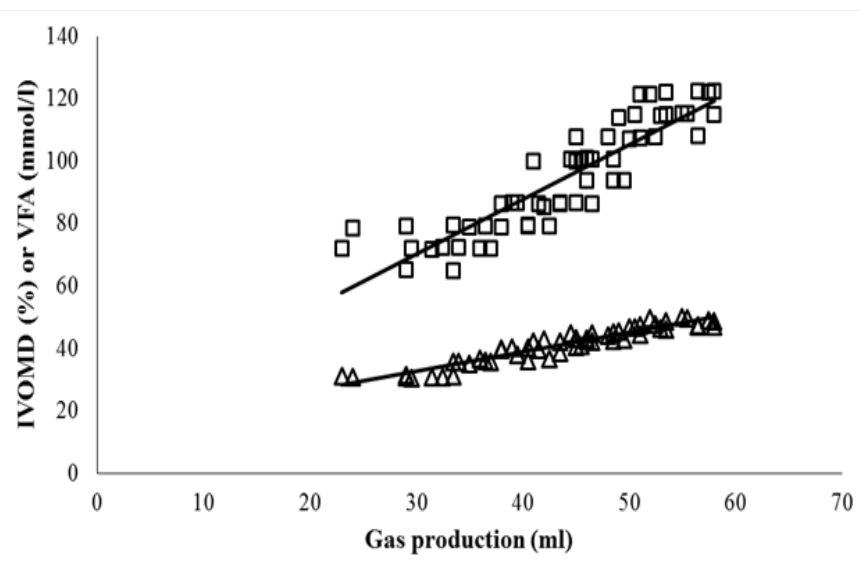

Figure 1: Relationship between in vitro gas production (ml) and in vitro organic matter digestibility (IVOMD; \%; $\Delta$ ) or total volatile fatty acid (VFA; mmol/l; $\square$ ) at $24 \mathrm{~h}$ incubation period.

$\operatorname{IVOMD}(\%)=14.0+0.622 \mathrm{Gas}(\mathrm{ml})(\mathrm{n}=56 ; \mathrm{P}<0.001$; $\left.\mathrm{R}^{2}=0.897\right)$

VFA $(\mathrm{mmol} / \mathrm{l})=17.7+1.753 \mathrm{Gas}(\mathrm{ml})(\mathrm{n}=56 ; \mathrm{P}<0.001$; $\left.\mathrm{R}^{2}=0.806\right)$

Methane emission in the rumen is formed by the action of methanogenic archaea such as Methanobrevibacter ruminantium, Methanosarcina barkeri, Methanosarcina mazei, Methanobacterium formicicum and Methanomicrobium mobile. Main substrates used for methane formation are hydrogen, carbon dioxide and formate (Morgavi et al., 2010). Lack of significant effect of FCT or urea + FCT treatments on OPEFB methane emission is apparently due to high variation of the methane data. On the other hand, an increase of DM or OM digestibility of OPEFB after FCT and/or urea treatment was accompanied by an increase of methane emission as well with relatively similar magnitude, thus contributing to similar methane values among treatments. Reduction of OPEFB fiber by FCT and/or urea treatment may induce a shift of VFA profile towards more propionate that leads to more hydrogen consumption and less methane. However, since total VFA concentration increases as well by the treatments, acetate concentration seems to increase and in turn shift back the methane emission to indifferent value.

\section{CONCLUSION}

Fiber Cracking Technology seems to be promising for improving nutritional quality of OPEFB especially when being combined with urea treatment. Improvement of OPEFB quality is linear with increasing level of urea and therefore, in the present experiment, use of 5\% urea + FCT shows the best nutritional quality among the treatments. Subsequent in vivo evaluation of OPEFB treated with urea + FCT is required to observe whether the treatment is able to effectively improve nutrient utilization and animal performance.

\section{ACKNOWLEDGEMENT}

This research was funded by Indonesian Ministry of Agriculture (Agency for Agricultural Research and Development) through "Kerjasama Kemitraan Penelitian dan Pengembangan Pertanian Nasional (KKP3N)” research grant year 2016.

\section{CONFLICT OF INTEREST}

All authors declare that there is no conflict of interest.

\section{AUTHORS CONTRIBUTION}

Anuraga Jayanegara designed and supervised the experiment, analyzed the data, wrote and revised the manuscript. Nabila F. Ardhisty and Sari P. Dewi performed the experiment and carried out laboratory analyses. Antonius, Roni Ridwan, Erika B. Laconi, Nahrowi and Muhammad Ridla supervised the experiment and revised the manuscript.

\section{REFERENCES}

-Abdul PM, Jahim JM, Harun S, Markom M, Lutpi NA, Hassan O, Balan V, Dale BE, Nor MTM (2016). Effects of changes in chemical and structural characteristic of ammonia fibre expansion (AFEX) pretreated oil palm empty fruit bunch fibre on enzymatic saccharification and fermentability of biohydrogen. Biores. Technol. 211:200-208. https://doi. org/10.1016/j.biortech.2016.02.135

- Akbar SA (2007). Pemanfaatan tandan kosong sawit fermentasi yang dikombinasikan dengan defaunasi dan protein by pass rumen terhadap performans ternak domba. J. Indonesian Trop. Anim. Agric. 32:80-85. 
-Ebrahimi M, Rajion MA, Meng GY, Shokryzadan P, Sazili AQ, Jahromi MF(2015). Feeding oil palm (Elaeis guineensis Jacq.) fronds alters rumen protozoal population and ruminal fermentation pattern in goats. Ital. J. Anim. Sci. 14:403-409 https://doi.org/10.4081/ijas.2015.3877.

- Garcia-Nunez JA, Ramirez-Contreras NE, Rodriguez DT, Silva-Lora E, Frear CS, Stockle C, Garcia-Perez M (2016). Evolution of palm oil mills into bio-refineries: Literature review on current and potential uses of residual biomass and effluents. Resour. Conserv. Recycl. 110:99-114. https://doi. org/10.1016/j.resconrec.2016.03.022

- Getachew G, Blummel M, Makkar HPS, Becker K (1998). In vitro gas measuring techniques for assessment of nutritional quality of feeds: a review. Anim. Feed Sci. Technol. 72:261281. https://doi.org/10.1016/S0377-8401(97)00189-2

- Groot JCJ, Cone JW, Williams BA, Debersaques FMA, Lantinga EA (1996). Multiphasic analysis of gas production kinetics for in vitro fermentation of ruminant feeds. Anim. Feed Sci. Technol. 64:77-89. https://doi.org/10.1016/ S0377-8401(96)01012-7

- Gunun N, Wanapat M, Gunun P, Cherdthong A, Khejornsart P, Kang S(2016). Effect of treating sugarcane bagasse with urea and calcium hydroxide on feed intake, digestibility, and rumen fermentation in beef cattle. Trop. Anim. Health Prod. 48:1123-1128. https://doi.org/10.1007/s11250-016-10612

-Imsya A, Laconi EB, Wiryawan KG, Widyastuti Y(2013). In vitro digestibility of ration containing different level of palm oil frond fermented with Phanerochaetae chrysosporium. Med. Pet. 36:131-136. https://doi.org/10.5398/ medpet.2013.36.2.131

-Jayanegara A, Kreuzer M, Leiber F (2012). Ruminal disappearance of polyunsaturated fatty acids and appearance of biohydrogenation products when incubating linseed oil with alpine forage plant species in vitro. Livest. Sci.147:104112. https://doi.org/10.1016/j.livsci.2012.04.009

-Jayanegara A, Dewi SP, Laylli N, Laconi EB, Nahrowi, Ridla M (2016). Determination of cell wall protein from selected feedstuffs and its relationship with ruminal protein digestibility in vitro. Med. Pet. 39:134-140. https://doi. org/10.5398/medpet.2016.39.2.134

- Jayanegara A, Ayinda RSK, Laconi EB (2017). Urea treatment of rice straw at elevated temperature and pressure: Effects on fiber content, rumen fermentation and digestibility. J. Indonesian Trop. Anim. Agric. 42:81-87. https://doi. org/10.14710/jitaa.42.2.81-87

- Laconi EB, Jayanegara A (2015). Improving nutritional quality of cocoa pod (Theobroma cacao) through chemical and biological treatments for ruminant feeding: in vitro and in vivo evaluation. Asian Australas. J. Anim. Sci. 28:343-350 https://doi.org/10.5713/ajas.13.0798.

- Mahmud-Ali A, Bechtold T (2015). Aqueous thiocyanateurea solution as a powerful non-alkaline swelling agent for cellulose fibres. Carbohyd. Polym. 116:124-130. https://doi. org/10.1016/j.carbpol.2014.04.084

- McCann JC, Sawyer JE, Wickersham TA (2017). Effect of source and level of protein supplementation on rice straw utilization by Brahman steers. J. Anim. Sci. 95:387-394. https://doi.org/10.2527/jas2016.0748

-Morgavi DP, Forano E,Martin C, Newbold CJ (2010).Microbial ecosystem and methanogenesis in ruminants. Animal. 4:1024-1036.https://doi.org/10.1017/S1751731110000546

- Morvay Y, Bannink A, France J, Kebreab E, Dijkstra J (2011). Evaluation of models to predict the stoichiometry of volatile fatty acid profiles in rumen fluid of lactating Holstein cows. J. Dairy Sci. 94:3063-3080. https://doi.org/10.3168/ jds.2010-3995

-Muhammad N, Nasir R, Li D, Lili Z, Tian W (2014). Effects of steam-treated rice straw feeding on growth, digestibility, and plasma volatile fatty acids of goats under different housing systems. Trop. Anim. Health Prod. 46:1475-1482. https:// doi.org/10.1007/s11250-014-0671-9

- Ooi ZX, Teoh YP, Kunasundari B, Shuit SH (2017). Oil palm frond as a sustainable and promising biomass source in Malaysia: A review. Environ. Prog. Sustain. Energy (in press). https://doi.org/10.1002/ep.12642

- Peripolli V, Prates ER, Barcellos JOJ, McManus CM, Wilbert CA, Neto JB, Camargo CM, Lopes RB (2014). Models for gas production adjustment in ruminant diets containing crude glycerol. Livest. Res. Rur. Dev. 26:\#28.

-Plaizier JC, Li S (2013). Prediction of in vitro dry matter digestibility with the ankom daisy II system of ruminant feeds using the gas production technique. Can. J. Anim. Sci. 93:399-402. https://doi.org/10.4141/cjas2012-153

-Sarnklong C, Coneja JW, Pellikaan W, Hendriks WH (2010). Utilization of rice straw and different treatments to improve its feed value for ruminants: a review. Asian Australas.J.Anim. Sci. 23:680-692. https://doi.org/10.5713/ajas.2010.80619

- Sinclair KD, Garnsworthy PC, Mann GE, Sinclair LA (2014). Reducing dietary protein in dairy cow diets: implication for nitrogen utilization, milk production, welfare and fertility. Animal. 8:262-274. https://doi.org/10.1017/ S1751731113002139

-Stichnothe H, Schuchardt F(2010). Comparison of different treatment options for palm oil production waste on a life cycle basis. Int. J. Life Cycle Assess. 15:907-915. https://doi. org/10.1007/s11367-010-0223-0

-Sulaiman F, Abdullah N, Gerhauser H, Shariff A (2010). A perspective of oil palm and its wastes. J. Phys. Sci. 21:67-77.

-Theodorou MK, Williams BA, Dhanoa MS, McAllan AB, France J (1994). A simple gas production method using a pressure transducer to determine the fermentation kinetics of ruminant feeds. Anim. Feed Sci. Technol. 48:185-197. https://doi.org/10.1016/0377-8401(94)90171-6

-Tilley JMA, Terry RA (1963). A two-stage technique for the in vitro digestion of forage crops. Grass Forage Sci. 18:104111. https://doi.org/10.1111/j.1365-2494.1963.tb00335.x

-Tsabitah S,Omar AA, Ismail L (2014). Chemical pretreatment comparison for oil palm empty fruit bunch: A Review. Appl. Mech. Mater. 625:851-855. https://doi.org/10.4028/www. scientific.net/AMM.625.851

- Van Soest PJ, Robertson JB, Lewis BA (1991). Methods for dietary fiber, neutral detergent fiber, and nonstarch polysaccharides in relation to animal nutrition. J. Dairy Sci. 74:3583-3597. https://doi.org/10.3168/jds.S00220302(91)78551-2

-Van Soest PJ (2006). Rice straw, the role of silica and treatments to improve quality. Anim. Feed Sci. Technol. 130:137-171. https://doi.org/10.1016/j.anifeedsci.2006.01.023 